Note

\title{
IN VITRO ESTABLISHMENT OF Heliconia rauliniana (HELICONIACEAE)
}

\author{
Paulo Hercilio Viegas Rodrigues \\ UFRN - Programa de Pós-Graduação em Genética e Biologia Molecular, Alameda das Mansões, 1178 - Candelária \\ -59067-010 - Natal, RN - Brasil.e-mail<phrviegas@hotmail.com>
}

\begin{abstract}
The great interest for heliconias by the external market has placed this crop in a prominent position in the flower production chain. The small offer of healthy seedlings, however, the expansion of this activity. The presence of endophytic microorganisms such as Pseudomonas sp. represents an obstacle even for the evolution of heliconia tissue culture studies. Stem apices of Heliconia rauliniana were inoculated and analyzed in vitro to investigate the presence of endophytic microorganisms. An antibiotic analysis was also run for posterior microbiological control. The presence of Pseudomonas sp. and Klebsiella sp. in stem apices confirmed infection. Antibiotics such as chloramphenicol, cefotaxime and the association of both (chloramphenicol + cefotaxime) at rates of 50,150,250 and $500 \mathrm{mg} \mathrm{L}^{-1}$, were applied to the MS medium and supplemented with $3.5 \mathrm{mg} \mathrm{L}^{-1}$ of 6-BA. After a 50 day-period, $500 \mathrm{mg} \mathrm{L}^{-1}$ of cefotaxime was the most efficient form to control endophytic microorganisms in this species of heliconia. The chloramphenicol, although effective for endophytic microorganism control, was inadequate for in vitro growth due to its cytotoxicity to explants. Key words: tissue culture, microbiologic control, endophytics
\end{abstract}

\section{ESTABELECIMENTO IN VITRO DE Heliconia rauliniana (HELICONIACEAE)}

\begin{abstract}
RESUMO: A acentuada procura por helicônias, principalmente por parte do mercado externo tem colocado o cultivo desse gênero de plantas em posição de destaque, dentre as atividades desenvolvidas no ramo da floricultura. A pouca oferta de mudas e a inexistência de mudas sadias prejudicam consideravelmente a expansão dessa cultura. A presença de microrganismos endofíticos, como a Pseudomonas sp., representa um empecilho no desenvolvimento de trabalhos de cultura de tecidos em helicônias. Ápices caulinares de Heliconia rauliniana foram inoculados in vitro e avaliados quanto aos tipos de microrganismos endofíticos e análise de antibiograma para posterior controle microbiológico. A presença de Pseudomonas sp. e Klebsiella sp. nos ápices caulinares estudados, comprova a presença dos endofíticos. Os antimicrobianos cloranfenicol, cefotaxima e a forma associada cloranfenicol + cefotaxima em doses $50,150,250$ e $500 \mathrm{mg} \mathrm{L}^{-1}$, foram aplicados ao meio MS, suplementado com 3,5 $\mathrm{mg} \mathrm{L}^{-1}$ de 6-BA, como forma de controle. Após 50 dias de avaliação, a cefotaxima aplicada isoladamente, na dose $500 \mathrm{mg} \mathrm{L}^{-1}$, foi a forma mais eficiente de controle dos endofíticos para esta espécie de helicônia. O cloranfenicol, apesar do controle efetivo dos endofíticos, mostrou-se inadequado ao cultivo in vitro, sendo cito-tóxico aos explantes.

Palavras-chave: cultura de tecidos, controle microbiológico, endofítico
\end{abstract}

\section{INTRODUCTION}

Heliconias (Heliconiaceae, Heliconia) are plants of commercial interest as garden or cut flowers. They are herbaceous, erect, with underground rhizomes, and depending on the species, their height varies between 0.5 to $8.0 \mathrm{~m}$. Native from the tropical regions of Central and South America, heliconia can be found in Peru, Colombia and in Brazilian tropical forests like 'Mata Atlântica' (Kress, 1990). More than 350 species have already been described, both wild and domesticated, most of them having as habitat the Amazonian region. The genus presents six species threatened by extinction, classified in a vulnerable category (IBAMA, 1999).
Heliconia cultivation is presenting, nowadays, significant expansion in small and medium farms, mostly in the Brazilian northern 'Zona da Mata', due to the beauty and high value of the flowers in the Brazilian and international markets. The reduced propagules offer makes the cost of production high in Brazil (Lamas, 2001). Quite a few research centers have dedicated efforts to study heliconia in Brazil, mainly the aspects related to the in vitro cultivation to produce healthy propagules through micropropagation techniques.

Biotechnological methods might contribute to solve some constraints for heliconia cultivation such as the long period required for seed germination (from three months to one year) and the underground rhizome multi- 
plication that takes a long time and cannot be properly followed up (Atehortua, 1997).

The identification of the endophitic bacteria Pseudomonas solanacearum accomplished by Atehortua (1997) and Dias \& Rodrigues (2001) and its control recommended by Dias (2002), using the combination of two antibiotics for different in vitro explants of $H$. bihai (Lobster Claw I), have contributed to the improvement of tissue culture and the production of heliconia healthy propagules in a wide scale. Therefore, this research aims to develop an in vitro establishment protocol for Heliconia rauliniana, an important commercial heliconia species.

\section{MATERIAL AND METHODS}

Apices of Heliconia rauliniana, obtained from lateral buds of $15.0 \mathrm{~cm}$ length were reduced to $2.5 \mathrm{~cm}$ diameter and $6.0 \mathrm{~cm}$ length by removing leaves and rhizome tissue. The stem apices were rinsed in tap water, followed by disinfestation by immersion in a commercial sodium hypochlorite solution $(30 \% \mathrm{v} / \mathrm{v}, 2.5 \% \mathrm{NaOCl})$ containing $0.1 \%$ of Tween- 80 for 20 minutes. Plant parts were, thereafter, rinsed three times with sterile deionized water.

After disinfestation, stem apices were trimmed to $0.5 \mathrm{~cm}$ diameter and $1.0 \mathrm{~cm}$ length and inoculated in MSmedium (Murashige \& Skoog, 1962) supplemented with 'Phytagel' (2.0 $\left.\mathrm{g} \mathrm{L}^{-1}\right)$; vitamins of Morel (Morel \& Wetmore, 1951); sucrose $\left(30.0 \mathrm{~g} \mathrm{~L}^{-1}\right)$; 6-benzyladenine (6BA) (3.5 mg L $\left.{ }^{-1}\right)$; and $\mathrm{pH}$ adjusted to 5.8. Each treatment had 20 replications, which were weekly evaluated for contamination, oxidation and growth. The presence of bacterial exudates in the shoot apex and/or bacterial growth were characterized as contamination, while the gradual darkening of explants until death was characterized as oxidation.

In contaminated explants, pathogen isolation was performed in a selective MacConkey medium and Agar Blood, according to Koneman et al. (2001). Biochemical tests employing Mini API V1.0.0 (BioMérieux) were accomplished for genus identification and antibiograms were run using disks with $30 \mu \mathrm{g}$ of the following antibi- otics: AMI- Amicacine, AMP- Ampiciline, ATMAztreonam, CAZ- Ceftazitime, CLO- Chloramphenicol, CFD- Cefalodril, CFL- Cefalexine, CTX-Cefotaxime, GN- Gentamicin, NET- Netilmicin, SUTSulphametoxazol/Trimetropine, TB- Tobramicine and TET - Tetracycline.

To evaluate microbial control and cytotoxicity, the antibiotics chloramphenicol and cefotaxime were tested using the same disinfestation procedures on stem apices of $H$. rauliniana and the MS-medium. Concentrations of $50,150,250$ and $500 \mathrm{mg} \mathrm{L}^{-1}$ of chloramphenicol, cefotaxime and the association of both (resulting concentrations of $0+0,50+50,150+150,250+250$ and $500+500 \mathrm{~m} \mathrm{~L}^{-1}$ ) were used. Ten replicates of each treatment were evaluated 50 days after experiment set up and statistical comparisons were made using Fisher's exact test (Gomes, 1987).

\section{RESULTS AND DISCUSSION}

Explant contamination was observed in cultures with the presence of two bacteria of the genera Pseudomonas and Klebsiella, confirming the reports of Atehortua (1997) and Dias \& Rodrigues (2001) that Pseudomonas sp. is an in vitro contaminant of heliconia (Table 1). Dias \& Rodrigues (2001) observed the presence of the same endophytic microorganism in $\mathrm{H}$. bihai. This suggests the existence of a common pattern in heliconia that would facilitate the endophytic control procedures.

After a 50-day in vitro growth period the microbiological control evaluation test presented high efficiency of chloramphenicol in eliminating microorganisms at $150 \mathrm{mg} \mathrm{L}^{-1}$. However, in spite of its efficiency, chloramphenicol proved to be inadequate for in vitro cultivation of heliconia due to its cytotoxicity, characterized by explant oxidation (Table 2). Cefotaxime at $500 \mathrm{mg} \mathrm{L}^{-1}$ was efficient in microorganism control, showing at this concentration, $30 \%$ of explant contamination, with a significant difference when compared to other concentrations $(P=0.0031)$. At the end of the evaluation period healthy explants were not oxidized and produced the initial buds (Table 2). The association of chloramphenicol and

Table 1 - Identification of bacterial contamination and antibiogram of Heliconia rauliniana explants cultured in vitro.

\begin{tabular}{|c|c|c|c|c|}
\hline \multirow{2}{*}{ Explant } & \multirow{2}{*}{ Bacteria } & \multicolumn{3}{|c|}{ Sensibility degree } \\
\hline & & Sensible & Less Sensible & Resistent \\
\hline \multirow{2}{*}{ Stem Apex } & Pseudomonas sp. & $\begin{array}{l}\text { AMI, ATM, CAZ, CFD, CTX, CLO, GN, } \\
\text { NET, SUT, TB, TET }\end{array}$ & AMP & CFL \\
\hline & Klebsiella sp. & $\begin{array}{l}\text { AMI, ATM, CAZ, CLO, CTX, GN, NET, SUT, } \\
\text { TB, TET }\end{array}$ & ---- & AMP, CFL, CFD \\
\hline
\end{tabular}

AMI - Amicacine, AMP - Ampiciline, ATM - Aztreonam, CAZ - Ceftazitime, CLO - chloramphenicol, CFD - Cefalodril, CFL Cefalexine, CTX - Cefotaxime, GN - Gentamicin, NET - Netilmicin, SUT - Sulphametoxazol /Trimetropine , TB - Tobramicine , TET Tetracycline 
Table 2 - Heliconia rauliniana explant contamination and oxidation affected by chloramphenicol, cefotaxima and its combination after a 50-day period.

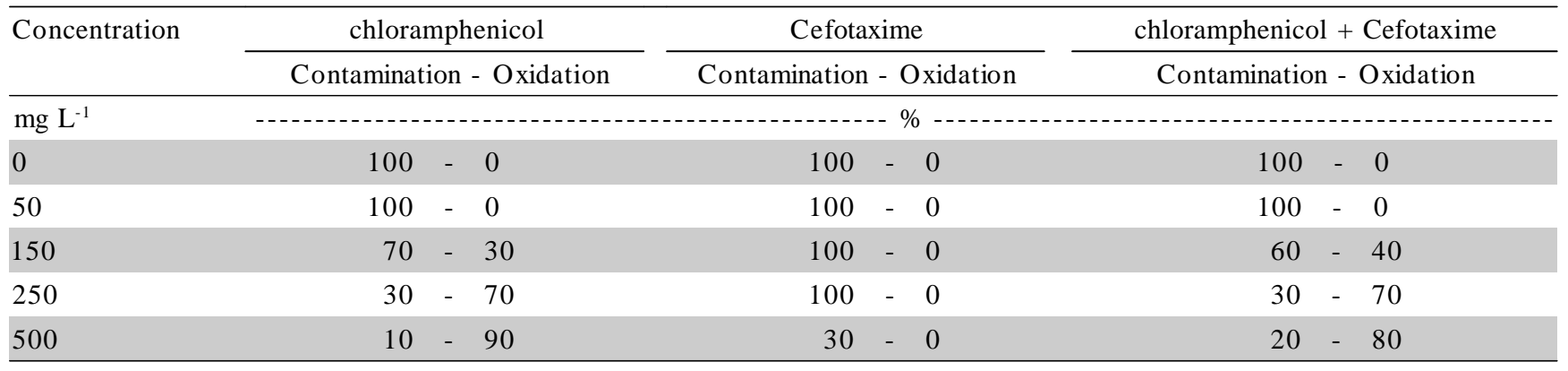

cefotaxime was inadequate for $H$. rauliana due to explant oxidation caused by chloramphenicol. These results are not in accordance with those reported by Reed et al. (1998), which eliminated Enterobacter spp. using a timentin + gentamicin combination for hazelnut, although half of the samples died due to phytotoxicity of the combination.

Dias (2002) verified that $H$. bihai presented similar behavior as compared to $H$. rauliana in response to the same antibiotics. The same efficiency level was observed for the application of $500 \mathrm{mg} \mathrm{L}^{-1}$ of cefotaxime, which promoted a $66 \%$ control in the stem apices.

\section{ACKNOWLEDGEMENTS}

To BioCampo Ltda and to CNPq (Projeto RHAE - inovação).

\section{REFERENCES}

ATEHORTUA, L. Heliconias: A new challenge for the Colombian floricultural industry. Biotechnology and Development Monitor, v.31, p.2021, 1997.

DIAS, M.A.S. Determinação de fontes de explantes em Heliconia (Heliconia bihai, ANGIOSPERMAE, HELICONIACEAE), isolamento, identificação e controle de microrganismos envolvidos nas dificuldades de cultivo in vitro. Natal: UFRN, 2002. 86p. (Dissertação - Mestrado).
DIAS, M.A.S.; RODRIGUES, P.H.V. Fontes de explantes e contaminantes isolados em cultivo in vitro de Heliconia bihai (HELICONIACEAE) Revista Brasileira de Horticultura Ornamental, v.7, p.165-168, 2001. GOMES, F.P. Curso de estatística experimental. 12.ed. São Paulo: Nobel, 1987. 466p.

INSTITUTO BRASILEIRO DO MEIO AMBIENTE E RECURSOS NATURAIS RENOVÁVEIS. Lista oficial de espécies da flora brasileira ameaçada de extinção. Portaria n ${ }^{\circ} 37-$ N.3 abril de 1999. Brasília, 1999.

KONEMAN, E.W.; ALLEN, S.D.; JANDA, W.M.; SCHRECKENBERGER, P.C.; WINN, W.C. Diagnóstico microbiológico - meios seletivos e diferenciais MacConkey. 5.ed. Rio de Janeiro: MEDSI, 2001. 1465p.

KRESS, W.J. The diversity and distribution of Heliconia (Heliconiaceae) in Brazil. Acta Botanica Brasílica, v.4, p.159-167, 1990.

LAMAS, A.M. Floricultura tropical: técnicas de cultivo. Recife: SEBRAE/ PE, 2001. 88p.

MOREL, G.; WETMORE, R.H. Tissue culture of monocotyledons. American Journal of Botany, v.38, p.138-140, 1951.

MURASHIGE, T.; SKOOG, F. A revised medium for rapid growth and bioassays with tabacco tissue cultures. Physiologia Plantarum, v.15, p.473-497, 1962.

REED, B.M.; MENTZER, J.; TANPRASERT, P.; YU, X. Internal bacterial contamination of micropropagated hazelnut: Identification and antibiotic treatment. Plant Cell, Tissue and Organ Culture, v.52, p.67-70, 1998.

Received October 24,2003

Accepted December 09, 2004 